\title{
A Century of Change in Personal Injury Law
}

\author{
Stephen D. Sugarman $\dagger$
}

\section{TABLE OF CONTENTS}

I. The Transformation of Personal Injury Law Doctrine.......................2406

A. The Failure of "Strict Liability" to Take Hold .............................2406

B. The Consolidation of the Primciple of Defendant Liability Based on Fault .2407

II. The Increase in the Ability and Willingness of People to Sue for Personal Injuries. .2409

A. Changed Cultural Meaning Attached to Suing for Personal Injury

B. A Better and More Specialized Plaintiff's Bar

C. Advertising and Proniotion

D. Availability of Expert Witnesses

E. Growth in Liability Insurance

F. An Increase in the Suns Obtainable for Pain and Suffering ..... 2413

G. An Apparent Much-Increased Willingness to Engage in Fraud to Collect a Tort Award.

III. The Narrowing of the Role of Tort Law Because of Its Perceived Inadequacy ..

A. Work Injuries Substantially Replaced with Workers' Conipensation.

B. Auto Injuries Partially Replaced by No-Fault Schemes. 2415

C. The Eclipse of Tort as the Vehicle for Dealing with Other Policy Problems.

IV. The Changing Pattern of Accidental Injuries and Death from 1900 to 2000 .

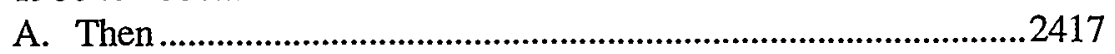

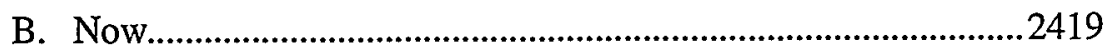

V. The Drannatic Change in Alternative Compensation Schemes........2421

Copyright $\odot 2000$ California Law Review, Inc. California Law Review, Incorporated (CLR) is a California nonprofit corporation. CLR and the authors are solely responsible for the content of their publications.

$\dagger \quad$ Agnes Roddy Robb Professor of Law, School of Law, University of California, Berkeley, (Boalt Hall). 
A. Enormous Expansion of Medical Care Access and Use.............2422

B. Dramatic Expansion of Income Replacement Protection...........2422

C. The Interplay of Insurance and Personal Injury Law .................2422

VI. A Great Expansion of the Regulatory Regimes Covering the

Main Types of Accidents Where Personal Injury Law Operates..... 2423

VII. Transformation in Legal Scholarship............................................2424

VIII. The Business of Personal Injury Law-Then and Now ................2426

IX. An Appraisal of How Well Tort Law Serves Our Society at the Start of the New Century 2428

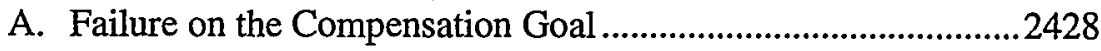

B. Qualms about Whether Justice Is Being Served.........................2429

C. Ineffective as Punishment...................................................2430

D. Deterrence-The Jury Is Still Out............................................... 2431

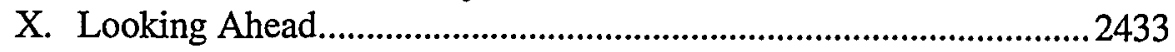




\title{
A Century of Change in Personal Injury Law
}

\author{
Stephen D. Sugarman
}

Over the past century, tort doctrine has coalesced around a robust law of negligence, anchored in both contemporary concerns about fairness and considerations of loss spreading and safety promotion. Changes in culture, the professions, civil procedure and evidence law, as well as the development of liability insurance, have made it easier and more natural for accident victims to sue. Work, home, and leisure activities have altered dramatically, thereby significantly changing the nature of the accidents that Americans now suffer. Some injuries were removed from personal injury law, and tort failed to take hold in certain other areas. The upshot is that the size and nature of the personal injury law system in the year 2000 differs enormously from the system in place in the year 1900. Nevertheless, many of the shortcomings of personal injury law in 1900 still plague tort law's operation today.

For well over 100 years, tort law has been a complex body of rules covering a wide range of civil injuries that, at times, have seemed rather unrelated to each other. Indeed, as late as 1900 it was by no means clear that "torts" was even a coherent field of the law or an identifiable subject of separate study. ${ }^{1}$ Nevertheless, the law of personal injuries has been at the heart of American tort law throughout the twentieth century. In this Essay, I will focus primarily on changing personal injury law and the changing personal injuries it handles. More precisely, my Essay will concentrate on accidental injuries. Although much legal doctrine exists that covers intentional personal injuries, personal injury law throughout the twentieth century, in practice at least, has been fundamentally about accidents. $^{2}$

1. See generally G. EdWARd White, TORT LAW IN AMERICA: AN INTEllectual History 18$19,38-39,60-62$ (1980).

2. By narrowing my Essay as 1 have, I do not mean to deny that business torts, for example, are an important area of the law-arguably one of rapidly growing importance today. So, too, tort law plainly deals with personal harms that involve other than physical injuries to the body-including harm to reputation which is protected by the law of defamation, the right to be left alone which is protected by privacy law, and so on. Furthermore, damage to tangible property is clearly a very important part of tort law's realm, and, of course, many bodily injuries are accompanied by damage to property as well-auto accidents being the exemplar. Nonetheless, because this is a brief essay with a 100 year 
The last 100 years have seen a significant change in the personal injuries with which tort law deals. Several forces have driven this change. First, tort law doctrine has been sharply altered. Second, the ability and willingness of accident victims to sue has markedly increased. Third, other forms of regulation have narrowed the role of tort law because of its perceived inadequacy. Fourth, the pattern of accidental bodily injuries is dramatically different today. I take these transformations up in Parts I-IV, respectively. After that, I address several other twentieth-century shifts in the background context of personal injury law: the creation of various social insurance arrangements, the development of the regulatory state and its attention to safety issues, and the enormous diversification in torts scholarship. Having reviewed these many changes, I then summarize how the business of personal injury law today differs from what it was in 1900. In the final sections of this Essay, I explore the questions of how well personal injury law serves our society as we begin the twenty-first century and what are the prospects for its future reform.

\section{I}

\section{The Transformation of Personal InJury Law Doctrine}

Personal injury law doctrine has changed significantly from the beginning to the end of the twentieth century. This transformation has not, however, resulted in the embrace of "strict liability" as many late twentieth-century advocates had hoped. Rather, defendant liability has consolidated around the "fault" principle.

\section{A. The Failure of "Strict Liability" to Take Hold}

Especially in the last third of the twentieth century, many tort scholars wrote on behalf of "enterprise liability." Guido Calabresi's work ${ }^{3}$ played a key role, as did the legal opinions of Roger Traynor. ${ }^{4}$ In terms of fairness, the basic vision behind "enterprise liability" is that those who choose to engage in business activities and gain the benefits from those activities ought to pay for the accident costs associated with them. Two key instrumental justifications for enterprise liability are that it prompts commercial actors to carry out their business more carefully (the deterrence objective), and that it spreads the financial loss from accidents among all those who buy from the enterprise, rather than concentrating the loss on unlucky victims (the risk-spreading objective).

As a doctrinal matter, "enterprise liability" in its strong form calls for the imposition of "strict liability" or "liability without fault" on

sweep, I have deeided to center my attention on accidental bodily injury. I also note that this portion of tort's work is what most contemporary law school courses on tort law feature.

3. Guido Calabresi, The Costs of Accidents (1970).

4. Most importantly, see Escola v. Coca Cola Bottling Co., 150 P.2d 436 (Cal. 1944). 
commercial sellers of goods, providers of commercial services, owners of commercial property, and so on. Yet, there has been very little acceptance of strict liability in tort. Strict liability law today is largely restricted to product injury cases involving manufacturing defects. ${ }^{5}$ And in that setting, strict liability usually makes little difference because victims typically could win anyway under negligence law, especially since the rule of res ipsa loquitur would commonly apply. Strict liability also applies to injuries caused by so-called abnormally dangerous activities, such as dynamite blasting, that occur despite the exercise of due care. ${ }^{6}$ But, by definition, these extra-hazardous activities and the injuries they cause are uncommon. ${ }^{7}$ So, while blasting injury and similar cases continue to provide fascination for the torts classroom, they matter little to the day-to-day life of tort law.

Scholars like Charles Gregory ${ }^{8}$ and Morton Horwitz ${ }^{9}$ have argued that during much of the nineteenth century (and before) tort law was dominated by strict liability. Were that actually so, then the twentieth-century transformation in tort doctrine might be described as one in which that prior way of thinking was soundly overruled. But the better reading of the historical record, as shown primarily by the work of Gary Schwartz, is that strict liability was highly unusual before the twentieth century as well. ${ }^{10}$

\section{B. The Consolidation of the Principle of Defendant Liability Based on Fault}

The central change in personal injury law doctrine that has taken place since 1900 is the evolution of a robust law of negligence. Making defendants take legal responsibility for accidents that they have unreasonably failed to prevent, but only for those accidents, is the core principle of personal injury law today. Interestingly enough, "enterprise liability" thinking has played a role here." The fault principle itself is increasingly defended on deterrence and risk-spreading grounds, rather than simply on the basis of fairness as between the plaintiff and the defendant.

Personal injury law's coalescence around the fault principle has resulted in a simplification of the substantive law in this area, a trend Harry

5. See Restatement (ThIRD) OF ToRTs: Products Liability § 2 (1998).

6. See Restatement (SECOND) OF TORTS \$\$ 519-20 (1977).

7. See id. $\$ 520$ (d) (describing such activities as "not a matter of common usage").

8. See Charles O. Gregory, Trespass to Negligence to Absolute Liability, 37 VA. L. Rev. 359 (1951).

9. See Morton J. Horiwtz, The Transformation of American Law, 1780-1860, at 67-108 (1977).

10. See Gary T. Schwartz, The Character of Early American Tort Law, 36 UCLA L. Rev. 641 (1989); Gary T. Schwartz, Tort Law and the Economy in Nineteenth Century America: A Reinterpretation, 90 YALE LJ. 1717, 1727-34 (1981).

11. See Robert L. Rabin, Some Thoughts on the Ideology of Enterprise Liability, 55 MD. L. REv. 1190 (1996). 
Kalven noted three decades ago. ${ }^{12}$ The most important shift in doctrine since 1900 has been the elimination of many long-standing rules that previously immunized defendants from liability, a theme best explored in an article published twenty years ago by Robert Rabin. ${ }^{13}$

In the nineteenth century (and well into the twentieth), tort law contained many rules that limited a defendant's legal duty. Although juries might well have concluded that reasonable precautions were available to defendants that would have prevented harm to victims, judges applied legal doctrines that protected those defendants from liability. By the end of the twentieth century, however, this picture had been radically altered. In the first place, many old "no duty" rules have been abandoned. Perhaps most important is the overthrow of the rule that manufacturers owed no duty of care to consumers for harms done to them as a result of negligently made products, unless the consumer had bought the product directly from the manufacturer (the "privity" requirement) - an uncommon practice in a modern world dominated by independent retailers. Cardozo's justly famous opinion in the MacPherson case prompted this change in the law relatively early in the twentieth century. ${ }^{14}$ Since then, many other "no duty" rules have also fallen. For example, emotional distress claims no longer require physical touching to be actionable, ${ }^{15}$ land owners and occupiers are liable to trespassers and social guests in circumstances in which they previously owed those victims no duty of care ${ }^{16}$ and intrafamily immunity (another "no duty" principle) has been widely abandoned. ${ }^{17}$ The general acceptance of "enterprise liability" thinking (both the deterrence and riskspreading objectives) helps explain why exempting these various defendants from liability would seem so odd to most lawyers and academics at the end of the twentieth century.

Second, the common law has expanded to find new duties where few people earlier would have dreamed they could exist. Auto makers now have a duty to exercise due care in making their vehicles reasonably safe in the event of crashes; ${ }^{18}$ physicians have a duty to conform to national standards of medical practice ${ }^{19}$ and to disclose to their patients the risks of proposed medical treatment (and nontreatment); ${ }^{20}$ and commercial establishments must take affirmative steps to protect their customers from the

12. See Harry Kalven, Jr., Tort Law: Tort Watch, 34 ATL L.J. 1 (1972); Harry Kalven, Jr., Tort Law: Negligence on the Move, 33 ATL L.J. 1 (1970).

13. See Robert L. Rabin, The Historical Development of the Fault Principle: A Reinterpretation, 15 GA. L. REv. 925 (1981).

14. See MacPherson v. Buick Motor Co., 111 N.E. 1050 (N.Y. 1916).

15. See, e.g., Dillon v. Legg, 441 P.2d 912 (Cal. 1968).

16. See, e.g., Rowland v. Christian, 443 P.2d 561 (Cal. 1968).

17. See, e.g., Waite v. Waite, 618 So.2d 1360 (Fla. 1993).

18. See, e.g., Larsen v. General Motors Corp., 391 F.2d 495 (8th Cir. 1968).

19. See, e.g., Jones v. O'Young, 607 N.E.2d 224 (II1. 1992).

20. See, e.g., Korman v. Mallin, 858 P.2d 1145 (Alaska 1993). 
foreseeable dangers of criminal assaults on their premises. ${ }^{21}$ Again, "enterprise liability" thinking at least partially underlies these changes.

The emphasis of today's tort law in imposing financial responsibility on at-fault defendants is also reflected in the near universal rejection (typically by statute) of contributory negligence as a complete defense, a robust rule of tort law in $1900 .{ }^{22} \mathrm{Now}$, negligent defendants (certainly those who are predominately at fault) no longer escape merely because their victims also failed to exercise due care. Instead the financial loss of the accident is shared according to the relative fault of the parties. In the same vein, the assumption of risk defense, which was also vigorously applied in 1900 , has now been contained, albeit (alas) not eliminated. ${ }^{23}$

The upshot, therefore, is that, although the jury must be convinced that the defendant was at fault, many a victim's legal burden in personal injury cases is considerably lighter than it was a century ago.

II

\section{The Increase in the Ability and Willingness of People to Sue for Personal InJURIes}

In 1900, misfortune was a more accepted part of life. Today, people are more willing to blame others for their injuries and go to court to obtain redress. In this section I want discuss a variety of ways in which people's ability to pursue tort remedies has been enhanced over the past 100 years. Along the way I will cominent on how these and other factors may have influenced tort victims' willingness to sue.

\section{A. Changed Cultural Meaning Attached to Suing for Personal Injury}

In the past in many commumities, suing in tort would stigmatize the plaintiff. Sumg was seen as a hostile and inappropriate act. Accident victims were told to just "lump it" or, perhaps, reach a quiet informal resolution of their concerns without litigation.

Now, in many communities the exact opposite norm prevails. People are expected to sue if they are injured. They may be made to feel the fool if they don't. Friends and family encourage accident victims to "get theirs"

21. See, e.g., Kline v. 1500 Mass. Ave. Apartment Corp., 439 F.2d 477 (D.C. Cir. 1970).

22. See Williams v. Delta Int'1 Mach. Corp., 619 So.2d 1330 (Ala. 1993).

23. See, e.g., Knight v. Jewett, 834 P.2d 696 (Cal. 1992). See generally, Stephen D. Sugarman, The Monsanto Lecture: Assumption of Risk, 31 VAL. U. L. REv. 833 (1997). The prominence of "fault" in personal injury law has further increased because the law now downplays rules of causation as ways for defendants to escape liability. Careless defendants, who earlier escaped liability because of narrow applications of the "but for" test of causation, now often must face the more liberal "substantial factor" test. See, e.g., Mitchell v. Gonzales, 819 P.2d 872 (Cal. 1991). Careless defendants who previously were able to hide behind the plaintiff's inability to identify which specific defendant actually "did it" are now sometimes held responsible on the basis of "alternative liability," "concerted action," or "market share" theories. See, e.g. , Hymowitz v. Eli Lily \& Co., 539 N.E.2d 1069 (N.Y. 1989). 
since "everybody else is doing it." Many victims are eager to see themselves as entitled to recovery from another, and are eager to transfer blame for their predicament away from themselves and to another if at all possible. Many quickly buy into the idea that by suing they are a modern day version of David on the attack against the evil Goliaths in our society (businesses, insurance counpanies, governments, and the like).

In some quarters, accident victims today are viewed as too aggressive, too selfish, too greedy and so on. But this point of view may well fail to constrain litigation, even if the victim perceives it. Perhaps the greater "individualism" of our society is relevant here. Perhaps the concentration of our population in larger, nore anonymous urban areas is as well. The media may also have played a role: in recent years, newspapers, popular magazines, and TV have appeared to give much greater attention to personal injury cases and the large awards made in some of them.

\section{B. A Better and More Specialized Plaintiff's Bar}

For a large part of the twentieth century, personal injury lawyers were widely and disparagingly viewed as sleazy "ambulance chasers" who worked on the fringe of the profession, doing personal injury work because they were not talented enough to succeed at other kinds of law. Starting fairly early in the century, canons of legal ethics were widely adopted that were designed in large part to rein in practices of many who practiced personal injury law. ${ }^{24}$ The social status of the personal injury bar is still controversial today, and some lawyers continue to make their living by running "mills" that process vast numbers of small (mostly auto accident or slip and fall) cases by negotiating settlements with insurance company adjustors. Little "law" is practiced by these attorneys, and some of them still obtain clients through what are generally thought to be unsavory practices, such as paying hospital orderlies and other "runners" to hand out their business cards.

However, as we enter the twenty-first century, the reputation of personal injury lawyers is much changed. Now, the elite members of the personal injury bar are among the wealthiest and most famous big shots in the profession, and in some quarters they are among the most admired. ${ }^{25}$ Although the stars of this sector of the profession still attract scorn, those who obtain tens of millions of dollars in fees from class actions, toxic spills, and the like, and those who are now obtaining hundreds of millions

24. See Henry S. Drinker, Legal Ethics 63-65, 210-73, 309-25 (1953) (discussing "ambulance chasing," and advertising and solieitation, as well as the 1908 canons adopted by the American Bar Association and the First Code of Profcssional Ethics adopted in the United States by the Alabama State Bar Association in 1887); see also Max Radin, The Achievements of the American Bar Association: A Sixty Year Record, 26 A.B.A. J. 135 (1940).

25. See, e.g., John A. Jenkins, The Litigators: Inside the Powerful World of AMERICA's High-Stakes Trial LaWyers (1989). 
(or even billions) in fees from tobacco litigation, are clearly no longer fringe actors. They have become prominent players in the legal world. The changing status of personal injury legal work is also reflected by the fact that, on the defense side, many large, big-city, elite law firms that earlier on would not touch personal injury defense work are now lead counsel on behalf of defendants in many important cases.

The upshot is that today it is widely recognized that many financially successful "trial lawyers" (a phrase, oddly, that has been usurped by the plaintiffs' side) are extremely effective lawyers. Perhaps this is because this part of the profession is now so much more lucrative. ${ }^{26}$ Whatever the reason, it means that victims are increasingly likely to find someone who is highly competent to represent them.

Moreover, many personal injury lawyers now specialize. If a family member is a plane crash victim, there are several experts in plane crash cases to whom one might turn. If medical malpractice is your complaint, you can find many lawyers who do only, or mostly, these sorts of cases. In the product injury field, victims can find lawyers who specialize in certain types of products. This sort of specialization also tends to raise the average quality of the representation victims obtain.

The plaintiff side has also been helped by organized cooperation among trial lawyers. Although most personal injury lawyers still work on their own or in relatively small firms, the creation of their national trade association, the Association of Trial Lawyers of America (ATLA), and its state counterparts has provided important forums that benefit plaintiffs. ${ }^{27}$ For one thing, these associations serve as vehicles for lawyers to exchange information on similar cases on which they are working. For another, they have become the groups through which effective state-level political lobbying and campaign contributing take place. This political activity, of course, is primarily pursued on behalf of the interests of the trial lawyers themselves. But what is good for them tends to be good for plaintiffs too (which is not the same as saying that it is necessarily good for all accident victimes or for society as a whole, a topic I take up in Parts IX and X).

\section{Advertising and Promotion}

Access to personal injury lawyers, and hence access to the courthouse, has also been enhanced by the legalization of, and intensive investment in, forms of marketing that were considered both unethical and illegal in the past. With the help of the U.S. Supreme Court's "commercial free speech"

26. For recent empirical evidence on the personal injury bar, see Herbert M. Kritzer, The Wages of Risk: The Returns of Contingency Fee Legal Practice, 47 DEPAUL L. REV. 267 (1998).

27. See Association of Trial Lawyers of America (visited June 27, 2000) <http://www.atla.org>. 
doctrine, ${ }^{28}$ personal injury lawyers now openly advertise on TV, via the Internet, in the yellow pages, on public transport vehicles, and so on. This change is likely to generate not only more clients for the advertisers, but also more public awareness of the existence of these legal services, how to find them, what they cost, and so on, thereby eliminating inhibitions that previously might have prevented some victims from seeking legal relief.

\section{Availability of Expert Witnesses}

A bigger, more urban nation, more money flowing through the tort system, less collegiality among physicians and others, and changing rules of evidence have combined to make it much easier for today's plaintiffs' lawyers to find credible expert witnesses to testify on behalf of their clients. Earlier in the century, for example, when the malpractice standard was based on local practice, getting one of a town's doctors to testify against another in a malpractice case was almost impossible. This difficulty effectively preempted most malpractice litigation regardless of whether serious malpractice had occurred. Today, with a malpractice standard based on national norms, finding a plaintiff-side qualified medical expert today is easy (assuming one has a plausibly valid case, or perhaps even if not).

\section{E. Growth in Liability Insurance}

It has almost never paid to sue in tort if the person you are suing is effectively financially judgment proof. While tortfeasors today who are insolvent, or nearly so, remain unpromising targets of litigation, the flowering of the liability insurance industry in the twentieth century has improved the recovery prospects for personal injury victims.

Motorists in most states are required to be insured, and although perhaps one in six is not, ${ }^{29}$ the great majority are now able to provide at least some tort compensation to anyone they negligently injure. Without that insurance, many fewer auto claims would be brought. Insurers have also built liability insurance (for non-auto accidents) into standard homeowner (and renter) insurance policies. So, what was traditionally intended to provide insurance against fire and theft has expanded not only to protect the injurer's other assets, but also to provide a deep pocket from which tort victims may be paid. On the commercial side as well, small merchants, who previously would have gone bankrupt if subjected to a tort claim, now typically have general commercial liability insurance, thereby providing an

28. For the development of legal doctrine as applied to marketing by lawyers, see Florida Bar v. Went For It, Inc., 515 U.S. 618 (1995).

29. See J. Daniel Khazzoom, What We Know about Uninsured Motorists and How Well We Know What We Know, Resources for the Future Discussion Paper 98-09; David W. Sommcr et al., Financing Uninsured Motorists, 13 J. of Ins. Reg. 359 (1995). 
opportunity for litigation to succeed that frequently would not have been attempted in the past.

\section{F. An Increase in the Sums Obtainable for Pain and Suffering}

Although tort law has formally awarded general damages for the pain and suffering that accompanies personal injuries throughout the twentieth century, the sunis juries award today (and in turn the sums lawyers can win for their clients in settlenient of claims) dwarf those of 100 years ago, even accounting for inflation. ${ }^{30}$ It stands to reason that the prospect of a larger award increases the willingness of victims to sue. This is especially true in today's world in which niany victinis, as discussed below, already have their health care and wage replacement needs reasonably assured.

If a personal injury lawsuit promised victinus little more than they could get without it, or if most of what more it promised would wind up in the lawyer's pocket, then the incentive to sue would be modest. But if, even after paying your lawyer, you can net out a great deal more than is necessary to pay for your out of pocket expenses, then the economics of litigation look very different.

Perhaps it is because our nation is so wealthy; perhaps it is because we use juries for torts cases when other countries do not; perhaps it is for other cultural reasons; but for whatever reason, the amount our legal system awards victims for pain and suffering is much, nuch greater than is obtainable elsewhere in the world. ${ }^{31}$

\section{G. An Apparent Much-Increased Willingness to Engage in Fraud to Collect a Tort Award}

One dark side to our generosity in the award of general damages is the incentive it creates to engage in fraud. And, alas, our personal injury systenı seems much more riddled with fraud than it was in the past (although data on this change is hard to come by). ${ }^{32}$ In any event, these days some people stage accidents, pretend accidents have occurred that did not, pretend they are niore injured than they actually are, receive (or pretend to receive) medical treatment they do not need, and so on, all in furtherance of wimning larger settlenients for pain and suffering. Sometimes these system abusers are victims acting on their own; sometimes they are in cahoots with lawyers, doctors and the like, perhaps even put up to their misconduct by the lawyers involved.

The bottom line is that, in addition to changes in tort law, changes in institutional and cultural facets of American life surrounding the personal

30. See the discussion in Seffert v. Los Angeles Transit Lines, 364 P.2d 337 (Cal. 1961).

31. For a discussion of pain and suffering award levels in Europe, see PAUL SzölLösY, Compensation For Personal InJuRY In Western Europe (1992).

32. See, e.g., Fraud Facts (visited June 27, 2000) <http://www.InsuranceFraud.org>. 
injury law system have facilitated a greater tendency by accident victims to seek financial remuneration from their injurers (or alleged injurers).

III

The Narrowing of the Role of Tort Law Because of Its Perceived INADEQUACY

In contrast to the two themes already explored, several other factors cause tort law in the year 2000 to function somewhat more narrowly than it otherwise might. During the course of the twentieth century, new institutional regimes in the work injury and auto injury areas have taken bites out of the business of personal injury law. Moreover, for several other newly identified social/political problems, tort law has failed to provide a satisfying solution, and so its role has been eclipsed by other regimes.

\section{A. Work Injuries Substantially Replaced with Workers' Compensation}

In 1900, injured workers had to sue in tort to recover damages from their employer for occupational injuries. This regime was widely thought to be inadequate to provide coverage for the lost wages and medical care that victims needed. As a result, early in the twentieth century, tort law was supplanted by the system of workers' compensation that still dominates the treatment of workplace injuries as we begin the twenty-first century. ${ }^{33}$ Moreover, unlike some other countries where victims can both file for an industrial injury benefit and sue, the United States adopted workers' compensation as a total replacement for tort claims against employers sounding in negligence. ${ }^{34}$ Thus, twentieth century American personal injury law has lost a large area of business (although lawsuits by workers against third parties, such as product liability claims against machine tool makers, is a thriving mini-industry). ${ }^{35}$

Interestingly enough, tort law has now partly or fully jettisoned three important doctrinal barriers faced by workers at the end of the nineteenth century: contributory negligence as a complete bar; assumption of risk when workers knowingly work in dangerous conditions; and the so-called fellow servant rule which restricted the principle of respondeat superior to cases in which the defendant company's tort was committed by a superior. Hence, many plaintiffs with workplace claims would actually fare far better today than they would have a century ago were tort law still available to them.

33. See generally Lawrence M. Friedman \& Jack Ladinsky, Social Change and the Law of Industrial Accidents, 67 Colum. L. Rev. 50 (1967).

34. See Arthur Larson, Workman's Compensation LaW $\$ 114.10$ (2000).

35. See generally 2 A.L.I., RePORTERS' STUdY: ENTERPRISE RESPONSIBILITY FOR PERSONAL INJURY 183-98 (1991). 
Nonetheless, at present there is little prospect that tort law will be widely reintroduced into the American law of workplace injuries. For one thing, employers today would strongly oppose such a change (even though they complain about workers' compensation costs being too high). In addition, while some successful claimants would do much better under tort law, a large share of workers still do better under workers' compensation than they would in tort. This is because so many worker injuries occur without fault or are the fault of the injured worker him or herself.

\section{B. Auto Injuries Partially Replaced by No-Fault Schemes}

In terms of number of suits, personal injury law's main business today concerns auto accidents, a point discussed at greater length below. My emphasis here is that in a few states (most importantly Michigan and New York) personal injury claims arising out of auto accidents have been substantially reduced by the adoption of auto no-fault laws, which extinguish legal rights of those suffering lesser injuries in return for assured compensation for out-of-pocket losses, regardless of who is to blame for the accident. ${ }^{36}$ So, here too, though personal injury law doctrine is generally more liberal today than before, a bite (at least in some states) has been taken out of its reach.

The following comprise the main indictments of tort law on the auto injury front: (a) dispute resolution costs are too great, causing undesirably high auto premiums; (b) reaching a suitable settlement of an auto claim takes too long and is an unhappy experience for all too many victims; (c) seriously injured victims are vastly undercompensated by the system; (d) fraudulent claims are encouraged and widely occur; and, relatedly, (e) small claims are paid off at excessive levels by insurers who are eager to clear their dockets and afraid to take a chance that juries might award victims extravagantly high sums. ${ }^{37}$

Auto no-fault can make substantial headway against all these problems. However, in the United States to date, no state has embraced a nofault scheme that effectively does so. Michigan has the most comprehensive auto no-fault plan in the United States, and while its no-fault plan does a fairly good job combating many of the problems just noted, that scheme does too little to compensate the most seriously injured victims (who are relegated back to tort). ${ }^{38}$ Quebec has implemented a very promising model, in which generous and prompt payments are made to all auto accident victims on a no-fault basis, tort claims are abolished, and auto premiums are

36. See James K. Hammitt \& John E. Rolph, Limiting Liability for Automobile Accidents: Are No Fault Thresholds Effective?, 7 Law \& POL'y 4 (1985).

37. See generally Stephen D. Sugarman, "Pay at the Pump" Auto Insurance (1993).

38. As of 2000 , wage loss protection in Michigan is limited to $\$ 3,760$ per month. See Mich. Comp. Laws. ANN. $\$ 500.3107$ (b) note (West 2000) (Informational Statement re: Procedural Guidelines Issued Pursuant to Act 306 of the Public Acts of 1969 as Amended). 
stunningly low. Nevertheless, the power of the plaintiffs' bar in the United States has blocked serious consideration of copying that solution here. ${ }^{39}$

\section{The Eclipse of Tort as the Vehicle for Dealing with Other Policy Problems}

Several important socio-political issues have come to the fore in the second half of the twentieth century that, in principle, are grist for the tort law mill. But often tort law has been eclipsed as the central mechanism by which our society deals with the problem. Here are a few examples.

Discrimination on the basis of race (and gender and so on) is one important instance. Despite some early decisions suggesting that such discrimination might be fought with tort suits sounding in "emotional distress," ${ }^{30}$ tort law has not become an important legal weapon of the civil rights movement. Instead, special statutory schemes, both federal and state, have done the heavy lifting, even as they sometimes provide tort-like remedies (including general dainages which compensate for the pain and suffering of having been a victim of discrimination).

Police misconduct, another problem area, could also be battled by lawsuits for battery, invasion of privacy, and so on. Instead, the "exclusionary rule," police review boards, and the like have been the frontline weapons. Moreover, to the extent that police brutality lawsuits are brought against individual officers, they tend to be based on federal civil rights laws ${ }^{41}$ that provide claimants advantages not available to them in regular tort claims.

Yet another example is the field of domestic violence. With tort law having swept aside the old immunity (or no duty) rules protecting one spouse from being sued by another and preventing children from suing their parents, one might have imagined that tort law would become an important tool in the fight against domestic violence, at least in non-poor households. Yet, although such claims are now sometimes brought, they remain quite rare. ${ }^{42}$ Instead, restraining orders, divorce law, police assistance, criminal complaints (and sometimes prosecutions), child protective services and foster care, special domestic violence statutes (providing their own remedies), and so on are the prime legal avenues through which domestic violence victims respond.

A final example concerns harm to the environment. While tort law can and sometimes still does provide remedies (both damages and

39. See Stephen D. Sugarman, Quebec's Comprehensive Auto No-fault Scheme and the Failure of Any of the United States to Follow, LES CAHIERS DE DROIT, numero special, 109 (1998).

40. See, e.g., Alcorn v. Anbro Eng'g Inc., 468 P.2d 216 (Cal. 1970).

41. Under 42 U.S.C. $\$ 1983$ most importantly.

42. See generally Ira Mark Ellman \& Stephen D. Sugarman, Spousal Emotional Abuse as a Tort?, 55 MD. L. REv. 1268 (1996). 
injunctions) for both public and private nuisances, ${ }^{43}$ tort has not been the main way our society legally combats environmental dangers. Instead, we have turned to special environmental laws and agencies with their own administrative mechanisms and remedies.

The preceding examples in this Part show how, as the twentieth century progressed, targeted solutions to pressing social/political problems have lessened the impact of tort law in certain spheres where it used to play or could have played a more prominent role.

\section{IV}

\section{The Changing Pattern of Accidental InJuries and Death From 1900 To 2000}

A fundamental change in personal injury law over the past century has been brought about because of change in the nature of the injuries themselves. Alterations in places of work, modes of transportation, and patterns of behavior have all contributed to differences in the types of injuries which occurred in the course of the century.

\section{A. Then}

In 1900 , the population of the United States was approximately 75 million. ${ }^{44}$ Although data on deaths, accidental deaths, causes of death, and industrial accidents are sketchy and inconsistent, a general picture emerges.

Despite conflicting reports, I estimate that there were probably around 100,000 accidental deaths in $1900 .^{45}$ Allocating the total number of accidental deaths to specific causes is also tricky. What is clear, however, is that railway accidents, drowning, fractures, and burns were important causes of accidental fatalities, and that injuries from other vehicles and machinery were not. ${ }^{46}$

43. See Restatement (SECOND) OF ToRTs \$ 822 (1977).

44. See U.S. Census Bureau, Statistical Abstract of the United States 39 tbl. 25 (1922).

45. Although detailed data from that period is available from only a limited number of states, one "vital statistics" report of the death rate between 1900 and 1909 shows it to be in the range of 15-20 per 1,000 (or 1,500-2,000 per 100,000) for a total of between 1.2-1.5 million deaths in 1900. See ForREST E. Linder \& Robert D. Grove, Federal Security Agency, Vital Statistics Rates in the UNITED STATES 1900-1940, at 122 (1976). A 1908 study, however, put the total number of deaths of males over age 15 in 1900 at just under 1.4 million. See Frederick L. Hoffman, Industrial Accidents, 17 BULL. OF THE BUREAU OF LAB. 417, 422 (1908). The "vital statistics" report shows that the death rate from "external causes" was less than 100 per 100,000, and that included suicide, acute poisoning, and homicide. See LINDER \& GROVE, supra, at 214-15. This would amount to somewhat less than 75,000 total deaths from "external causes"-or approximately $5 \%$ of all deaths reported in the relevant table. The 1908 study noted above, however, put the number of accidental deaths of males over 15 at just over 125,000 in 1900. See Hoffman, supra. In that study, accidents to males over 15 accounted for about $9 \%$ of all deaths to men in that age group.

46. According to the "vital statistics" report, the death rate from "accidental drowning" was 12.1 per 100,000, from "railroad accidents and injuries" 9.7 per 100,000, from "fractures" 9.2 per 100,000, 
Perhaps something like a quarter or more of the accidental deaths in 1900 were from work injuries. A 1908 study puts the number of fatal industrial accidents in the United States among employed males in the range of 30,000-35,000. ${ }^{47}$ British data from the same period suggest that men suffered around $98 \%$ of fatal work accidents. ${ }^{48}$

Nonfatal accidents, of course, were far more common than fatal ones, although how much harm is required for something to qualify as an accidental injury for these purposes is unclear. For example, one 1899 data set suggests that for every worker killed in railway accidents, there were more than fifteen injured sufficiently to have been counted. ${ }^{49}$ Another study reported some New York industrial accident data for the period 1901 to 1906 suggesting that there were perhaps forty times as many injuries as fatalities, and that, of the reported injuries, more than $80 \%$ were temporary. ${ }^{50}$

The role of recreational injury at this time is quite uncertain. For example, as already noted, drownings were common, but most of these could have been work-related deaths at sea.

and from "burns and scalds" 7.5 per 100,000 . These were the largest subcategories. By contrast, death rates per 100,000 were 1.4 from horse and vehicle injuries, 0.4 from injuries by machinery, 0.4 from injuries in mines and quarries, and 0.4 from electric shock. Death rates from streetcar and auto accidents in 1900 were too small to warrant separate categories (although streetcar death rates reached 3.8 per 100,000 in 1907 at a time when the auto accident death rate reached 0.7 per 100,000 ). See LINDER \& GROVE, supra note 45, at 214-15. The 1908 report, however, puts railroad deaths in 1900 at nearly twice that of drowning, and nearly three times that of burns and scalds (which, by the way, killed females at twice the rate of males); as with the "vital statistics" report, however, railroad deaths dwarfed machinery deaths. See Hoffman, supra note 45, at 423. If the "vital statistics" figures are to be believed, then approximately 7,300 persons died in 1900 from "railroad accidents and injuries." LINDER \& GROVE, supra, at 214-15. Other turn-of-the-century data about industrial accidents suggests that 2,200 railway employees were killed by railway accidents in 1899 . See W. F. Willoughby, Accidents to Labor as Regulated by Law in the United States, 32 BULL. OF THE DEP'T OF LAB. 1, 8 (1901). This implies (if the two data sets may be combined) that around 5,000 of those killed in railway accidents in 1900 were people other than employees, presumably passengers and those struck by trains at crossings, among others. The 1908 report at one point puts the total number of deaths from railroad accidents at around 6,000 in 1900. See Hoffman, supra note 45 (which is at least in the same ballpark as the "vital statistics" estimate of 7,300). On the other hand, this may just be a coincidence. As noted, the "vital statistics" data indicate a national death rate from mine and quarry accidents of 0.4 per 100,000 which implies a total of 300 such deaths, most of which probably were workers killed in mines and quarries. Yet, different industrial accident data suggest that there were nearly 1200 coal mining deaths in the U.S. in 1899. See Willoughby, supra at 18.

47. See Hoffman, supra note 45 , at 418 .

48. See id. at 421 .

49. See Willoughby, supra note 46 , at 8 . This amounted to a total of around 35,000 injuries or approximately 37 injuries for every 1,000 railway workers. See id. To get a feel for the dangerousness of other industries, I note that another part of that same study showed that the estimated injury rate in New York in 1899 was slightly more than 37 per 1,000 employees in the chemical, oil, explosives, pulp, paper and cardboard industries, and in public utilities; it was around 25 per 1,000 in the building industry and in metals and machinery industries; under 20 per 1,000 in stone and clay products, wood, food, tobacco, and liquors; under 10 per 1,000 in printing and textiles; only 3 per 1,000 in leather and just over 1 per 1,000 in clothing, millinery, and laundering. See id. at 25.

50. See Hoffman, supra note 45 , at 420 . 


\section{B. Now}

In 2000 , things are very different. The U.S. population has more than trebled, to over 275 million. ${ }^{51}$ The National Safety Council reports that there were about 92,000 accidental fatalities in the U.S. in $1998 .^{52}$ That is a very substantial drop in the accidental death rate since 1900 . The Council also calculates that in 1998 there were more than 200 accidents leading to disabling injuries for every accidental death. ${ }^{53}$ It is difficult to compare these figures with the 1900 data.

The Council further reports that motor vehicle accidents caused more than 40,000 deaths in 1998 , which is about $45 \%$ of all the accidental fatalities in that year..$^{54}$ This was, of course, a largely unheard-of source of death in 1900. In 1996, "falls" accounted for nearly 15,000 fatalities, and "poisoning by solids and liquids" and "drugs, medicaments and biologicals" each accounted for nearly 9,000 fatal injuries (although many of the deaths in the latter two categories were probably by suicide).$^{55}$ The three other most important categories of accidental fatalities that year, according to the Council, were "fires and flames" (around 4,000), "drowning, submersion" (around 3,500), and "complications, misadventures of surgical, medical care" (around 3000)..$^{56}$

Turning from deaths to accidental injuries, a 1989 study by the RAND Corporation (using a very different methodology from that used by the National Safety Council) found that nearly $20 \%$ of all accidents involved motor vehicles, about $40 \%$ involved slips and falls, and about $30 \%$ involved a varied set of products such as toys, sports equipment, household appliances, or industrial hand tools. ${ }^{57}$

51. See U.S. Census Bureau, Statistical Abstract of the United States 834 (1999).

52. See National Safety Council, Injury Facts (visited April 28, 2000) <http://www.nsc.org/lrs/ statinfo/99002.htm>.

53. See id. Somewhat different findings are presented in a Report to Congress published in 1989 , based largely on 1985 data, which distinguished among nonfatal accidents; that Report found that there were 15 times as many hospitalized injured persons as fatalities, and more than 300 times as many nonhospitalized injured persons as fatalities. DOROTHY P. RICE ET AL., COST OF INJURY IN THE UNITED STATES: A REPORT TO CONGRESS 1989, at xxi (1989).

54. See National Safety Council, supra note 52.

55. Id.

56. Id.

57. Deborah R. Hensler et al., COMPENSATION For ACCIDENTAL INJURIES IN the UNITED States 31 (1991). According to the National Safety Council, motor vehicles were responsible for about 11\% of all disabling injuries in 1998 (over 2 million in total). See National Safety Council, supra note 52. Some other highlights of the RAND study are that about $30 \%$ of accidents occurred while people were relaxing. See HENSLER, supra at 27. About a third reported suffering their accidents while in their own homes (or those of friends). See id. at 28. Seven percent were rated by RAND as "very serious" and an additional $21 \%$ were rated "moderately serious." Id. at 41 . The Report to Congress did not identify products as a cause of injury, as the RAND study did, but it estimated that, as among unintentional injuries, falls accounted for nearly half of hospitalizations and $13 \%$ of fatalities. See RICE, supra note 53, at xxi. In the Report to Congress, drowning remained a fatality category worth separate attention, accounting for about $6 \%$ of unintentional fatalities according to the Report to Congress, as 
The Consumer Product Safety Commission's National Electronic Injury Surveillance System (NEISS) provides more detailed information about the connection between consumer product injuries and treatment in hospital emergency rooms. ${ }^{58}$ In the NEISS data, the "product" category that accounts for the largest number of estimated injuries is "stairs, ramps, landings and floors." 59 The categories of "beds, mattresses, pillows," "chairs, sofas, sofa beds," "bathroom structures \& fixtures," "desks, cabinets, shelves, racks," "tables," and "doors" are also sources of a very substantial number of injuries. ${ }^{60}$ Although the Commission does not specify the cause of injury, a great share of all of the injuries so far mentioned from the NEISS data must be from falling off of, or bumping into, the listed products. Sports and other recreational injuries represent other important contributions to the accident rate, with the categories "basketball" and "bicycles \& accessories" leading the way, and "football," "baseball, softball," "playground equipment," and "exercise, exercise equipment" coming next. ${ }^{61}$

Reports on industrial injuries and fatalities also show substantial changes since 1900. A 1998 National Safety Council report states that the unintentional work death rate per 100,000 population was reduced by $90 \%$ between 1912 and $1998 .{ }^{62}$ This report estimates that there were 18,000 21,000 occupational deaths in 1912 , but that by 1998 , the number was reduced to 5,100 at a time when the workforce had more than trebled. ${ }^{63}$ Although transportation incidents were still the leading cause of workrelated fatalities, the pattern was much changed from 1900. Motor vehicle injuries accounted for about $40 \%$ of occupational fatalities in $1998,{ }^{64}$ but there were only eighty-three work-related railway fatalities that year. ${ }^{65}$

did bums and fires which accounted for about $6 \%$ of the fatalities and $3 \%$ of the hospitalizations. See id. The Report to Congress found that while the male injury rate was almost $40 \%$ higher than the female rate, the male death rate was nearly three times the female rate. See id. at 13. For motor vehicles, females actually had a higher injury rate than males, but the male death rate was two and a half times as great. See id.

58. In considering these data, note that the Commission's jurisdiction and the NEISS reports exclude certain products which are important causcs of accidental injuries, including motor vehicles, drugs, guns, and tobacco products. See Consumer Product Safety Commission, National Injury Information Clearinghouse (visited June 27, 2000) <http://www.cpsc.gov/about/clrnghse.html> (explaining NEISS); Consumer Product Safety Commission, Who We Are-What We Do For You (visited June 27, 2000) <http://www.cpsc.gov/cpscpub/pubs/103.html> (explaining jurisdiction).

59. NEISS Data Highlights, CONSUMER PRODUCT SAFETY Rev. (U.S. Consumer Product Safety Comm., D.C.), Fall 1999, at 3.

60. Id. at 6-7.

61. Id. at 3-4.

62. See National SAFETY CounciL, InJuRy Facts 48 (1999).

63. See id. This number should be compared with the estimate of $30,000-35,000$ occupational fatalities for 1900 noted earlier. See supra text accompanying note 47.

64. See National Safety Council, supra note 52.

65. See Bureau of Labor Statistics, United States Department of Labor, News (USDL 99-208) August 4, 1999 Table 1. 
The National Safety Council put disabling work injuries at about $20 \%$ of all accidental injuries in $1998,{ }^{66}$ a proportion in the same range as my estimate for 1900 . Yet, the type of work accidents has changed substantially. For example, the Bureau of Labor Statistics reports that there were 5.5 million occupational injuries in 1998 , plus another 400,000 occupational illnesses. ${ }^{67}$ Of those, mining accounted for only 29,000 and railroading a mere $8,600 .^{68}$ There were, by contrast, more than 1.5 million injuries in manufacturing, nearly 1.5 million in wholesale and retail trades, and 1.3 million in service industries. ${ }^{69}$

These data I have presented reflect, of course, the changing nature of the non-natural dangers that Americans faced at the end of the century as compared to the beginning. Our work, leisure, and home lives have altered enormously. Many previously dangerous activities have been either made much safer or largely abandoned. Yet all sorts of new dangerous activities have been taken up. Our enbrace of personal highway motor vehicles is plainly the inost significant change. One further point to note is that the data presented here so far focus on accidents, by which the studies mean soine acute event. But, we are now quite aware that many products "accidentally" cause not just acute trauma but disease as well. I will return to this theme in Part VIII where I conpare the business handled by today's personal injury law with that of a century ago.

\section{$\mathrm{V}$}

\section{The Dramatic Change in Alternative Compensation Schemes}

In 1900, if someone suffered an accidental personal injury or death, the adverse financial consequences would probably have been met, if at all, from personal savings, family and friends, churches and charities, or perhaps fledgling benevolent societies and, in a small share of the incidents, through personal injury law. By 2000 , for most Americans, this situation had dramatically changed due to the development of other compensation scheines.

66. See National Safety Council, supra note 52 . The RAND study found that about $21 \%$ of accidents were work related (plus about $5 \%$ more which were incurred while commuting to work). See HENSLER, supra note 57 , at 28.

67. See Bureau of Labor Statistics, supra note 65 , at 4 .

68. See id.

69. See id. Note that according to the National Safety Council, disabling occupational injuries numbered 3.8 million in 1998 (not 5.5 million as quoted in the Bureau of Labor Statistics report cited above), which amounted to more than 700 times the number of work-related deaths. See National Safety Council, supra note 52. In any event, it is difficult to compare these ratios with the 1900 data because the definition of a nonfatal injury has no doubt changed, and changes from report to report. 


\section{A. Enormous Expansion of Medical Care Access and Use}

In 1900 doctors certainly existed and they treated at least some of those in need, although medicine then was often far more an art than a science. Today, we have a system of sophisticated hospitals, a vast network of general physicians and specialists, and tremendous advances in the medical treatment of victims of both accidents and disease. And nearly all Americans today expect to be able to take advantage of these improvements.

They can do so primarily because of our health insurance system. Although America lags behind a large number of rich nations in failing to adopt a comprehensive national health insurance scheme, our patchwork quilt of arrangements nonetheless assures reasonable access to good quality health care to the vast majority of our citizens. ${ }^{70}$ Private employmentbased health insurance, Medicare for the elderly, and Medicaid for many of the poor or near poor provide most of the coverage. These are all twentieth-century developments.

\section{B. Dramatic Expansion of Income Replacement Protection}

Americans are also now much better protected against wage losses caused by personal injuries than they were in $1900 .^{71}$ For long term disability and death, our expanded Social Security system, first enacted in 1935, provides substantial income replacement benefits, in amounts that cover a reasonably high share of lost wages of those with relatively low earnings. Higher earners often have supplemental disability insurance and life insurance that is privately obtained or employment-based. For shortterm non-occupational disability caused by accident, a large share of U.S. workers has job-based sick leave and many have short-term disability insurance (which is now mandatory in a handful of states). ${ }^{72}$

\section{The Interplay of Insurance and Personal Injury Law}

These vast compensation arrangements have important implications for both personal injury law and workers' compensation schemes. These arrangements exist because people realize that they need insurance against health care costs whether or not the event that occasions their accident (or illness) is caused by the fault of another or at the workplace; and those dependent on their own wages or the wages of another also realize that what they need is around the clock protection, not just protection of those wages against disruption caused by a tort or a work injury.

70. See generally 1 A.L.I, RePorters' StUdY: EnTERPRISE RESPONSIBILITY FOR PERSONAL INJURY 129-56 (1991) (discussing public access to health insurance in a tort context).

71. See id. at 157-202 (discussing disability and life insurance as alternatives to tort law).

72. See Wilmer L. Kerns, Protection Against Income Loss During the First 6 Months of Illness or Injury, 57 SOC. SEC. BuLL. 88 (1994). 
But the consequence for those with good health insurance is that the benefits provided by both tort and workers' compensation are often redundant in dealing with the accident victim's health care needs. On the tort side this typically means either that the victim obtains a windfall double recovery (obtaining a cash payment to cover medical expenses that have already been paid for by insurance) or else, more commonly, that a complicated process is set in motion by which the health insurer recoups its expenses from the tort award, a process that adds significant transaction costs. Workers' compensation plans are typically "primary," and hence either they pay for the victim's health care directly, or else they reimburse regular health insurers for medical expenses arising out of work-related injuries for which those plans paid. But from the worker's perspective, the point is that those expenses would generally have been paid for anyway even if workers' compensation were unavailable.

On the income side, tort awards are generally added on top of whatever sick leave, disability insurance, life insurance and the like that is available to the accident victim and/or the victim's survivors in cases of death. Hence, wage losses are often doubly compensated. However, most of those suffering non work-derived, permanent, partial disabilities do not have non-tort disability insurance and may well have to rely on tort (when available) to provide for the accompanying loss in wages. On the job injury side, workers' compensation does provide benefits for partial, permanent disability (as well as temporary and permanent total disability and death), although this category of benefit is the most contentious and probably the most unsatisfactory part of the scheme in many states.

The main point, then, is that personal injury law serves a very different compensation function in the year 2000 than it would have served had these alternate compensation schemes not been created. Indeed, as a practical matter, the main compensation for many tort victims provided by the legal system is not for out of pocket economic losses. That is, a great deal of money is provided both for "pain and suffering" and to duplicate other sources of recovery. To be sure, the victim's legal expenses often consume a substantial share of this money. But enough still often goes to the victim to cause many to seek this extra compensation via litigation.

\section{VI}

\section{A Great Expansion of the Regulatory Regimes Covering the Main} TyPes OF ACCIDENTS WhERE PERSONAL INJURY LAW OpERATES

In Part III, I noted certain social issues over which tort law could have exerted a greater influence had its role not been eclipsed by other institutional arrangements. In this Part, I want to focus on areas in which personal injury law is thriving despite the twentieth-century development 
of parallel schemes aimed at preventing the same types of personal injuries that tort law is meant to deter.

As the motor vehicle has come to dominate our lives in the twentieth century, we have by no means been content to rely upon personal injury law to reduce highway injuries. A vast criminal law regime has been created to discourage, capture and punish careless drivers. A complex administrative regime has been developed to train, license, and re-license individual drivers. And to the extent that auto makers are seen to be part of this picture, they are answerable not only to personal injury lawsuits but also to the rules and regulations of the National Highway Transportation Safety Administration (NHTSA). ${ }^{73}$

Something of the same story could be told about injuries caused by the health care industry. Although doctors long seemed free from regulation, this is now rapidly changing as hospitals, insurers, state licensing boards, and other agencies have moved in to try to impact the quality of care provided. And on the drug and medical device side, the Food and Drug Administration plays an active role in protecting heath care consumers from dangers.

Whether these regulatory schemes duplicate, reinforce, or contradict tort law, or do some of each of those things, is a controversial matter. Nor do I mean to suggest here that any of these regulatory mechanisms is especially effective. Rather, the main point to be emphasized here is this: looking back to 1900, personal injury law was arguably society's main line of defense against certain types of unsafe conduct (even if it was not a very strong defense); today, by contrast, tort functions in an environment in which other complex, safety promoting, regulatory schemes also operate.

\section{VII}

\section{TRANSFORMATION IN LEGAL SCHOLARSHIP}

Just as tort law has changed, so too has the legal academy's approach to tort law. During the early decades of the twentieth century, torts scholarship was dominated by work on legal doctrine. Even though Oliver Wendell Holmes had some soaring things to say about torts in his famous 1881 lectures on the common law, ${ }^{74}$ the typical legal scholarship of that era focused on making sense of the rules. Indeed, many academics saw themselves as scientists out to discover the patterns in a mass of previously under-analyzed data in the form of legal opinions from around the nation.

73. Concerning the effectiveness of NHSTA over auto safety, see generally, Stephen D. Sugarman, Nader's Failures?, 80 CALIF. L. REv. 289 (1992).

74. Oliver Wendell Holmes, The Common Law (1881). 
A good example of that approach is Francis Bohlen's influential analysis of "incomplete privileges" published in 1926 in the Harvard Law Review. ${ }^{75}$

Although certain exceptions can be identified, attention to doctrine remained central in tort law scholarship until the 1960s, and is epitomized by two monumental achievements. First is the Restatement of the Law of Torts, a project of the American Law Institute initially issued in 1934 and revised in its second edition starting in the early 1960s (with portions of the Restatement Second dribbling out over many years). Second is the 1941 publication of William Prosser's treatise on Torts, which not only compiled a stupendous number of cases and rules, but also presented Prosser's own critique of some of them and his now famous calls for certain doctrinal changes that were later embraced by the courts.

Starting in the late 1960s, the focus in tort scholarship has changed dramatically. Writing about new doctrinal developments in tort law is now largely (although not entirely) the work of law students and practitioners. Professors, at least those who see themselves as "scholars" and especially those from the "leading law schools," have (alas) generally shunned writing about the details of tort doctrine. This is, of course, an exaggeration. Some of the best writing in torts by leaders in our field, like John Fleming, ${ }^{76}$ Robert Rabin, ${ }^{77}$ and Gary Schwartz ${ }^{78}$ has been about doctrinal matters-all of whom also, I should add, incorporate "new" dimensions in their work as well.

One of these "new" dimensions is the empirical study of tort law in action. This is the contribution of the "law and society" (or "socio-legal studies") movement to tort. Through the work of scholars like Deborah Hensler $^{79}$ and Marc Galanter ${ }^{80}$ we have a much better understanding of how the personal injury law system actually works than we ever did. Recently, the "case study" approach has further enhanced our understanding of tort law in action. In this approach, one case or a related series of cases is examined in depth, not so much in order to describe and critique the legal analysis of the judges in the published opmions, but more to understand what our personal injury law is about through the lens of a single problem.

75. Francis $\mathrm{H}$. Bohlen, Incomplete Privilege to Inflict Intentional Invasions of Interests of Property and Personality, 39 HARv. L. Rev. 307 (1926).

76. See, e.g., John G. Fleming, Comparative Negligence at Last-By Judicial Choice, 64 CALIF. L. REv. 239 (1976).

77. See, e.g., Robert L. Rabin, Enabling Torts, 49 DePaUl L. Rev. 435 (1999).

78. See, e.g., Gary T. Schwartz, Foreword: Understanding Products Liability, 67 CaLIF. L. Rev. 435 (1979).

79. See, c.g., HENSLER, supra note 57.

80. See, e.g., Marc Galanter, Real World Torts: An Antidote to Anecdote, 55 MD. L. REv. 1093 (1996). 
Peter Schuck's book on the Agent Orange controversy well illustrates this genre. ${ }^{81}$

Torts scholarship has also become highly interdisciplinary, or perhaps better put, personal injury law is increasingly being examined with the tools of, and from the vantage point of, other disciplines. "Law and economics" is perhaps most prominent, as illustrated first in the writings of Calabresi $^{82}$ and later, for example, in other pioneering work by Richard Posner, ${ }^{83}$ Steven Shavell, ${ }^{84}$ and many others. "Law and philosophy" has also had its say, as those with a moral philosophy bent, like Jules Coleman, ${ }^{85}$ Ernest Weinrib, ${ }^{86}$ and George Fletcher ${ }^{87}$ have weighed in to help us better understand the many notions of justice that tort law might, or does, serve. Perhaps latest on this scene are those, led initially by Howard Latin, ${ }^{88}$ who examine the contributions that cognitive psychology can bring to our understanding of tort law.

The main importance of all this scholarship, in my view, is that it provides insight into how we should appraise personal injury law as a whole, a matter to which I will turn in the final sections of this Essay.

\section{VIII \\ The Business of Personal InJury Law-Then and Now}

Having now surveyed changes in accident patterns and tort law's reach during the twentieth century, as well as other background factors relevant to tort law, let me sketch the main differences I see between the business of personal injury law in 1900 as compared with 2000 .

In his study of tort law in Alameda County, California, at the end of the nineteenth century, Professor Lawrence Friedman reports that only about seventeen personal injury lawsuits per year were filed in the county between 1880 and $1900 .{ }^{89}$ Tort cases were only $2 \%$ of the superior court filings between 1880 and $1900 ; ;^{90}$ by contrast, they were more than a quarter of the cases in 1970, when the rate of filing had grown from 1 in 2,200 persons in the county to 1 in $333 .{ }^{91}$ In the last two decades of the nineteenth

81. Peter H. Schuck, Agent Orange on Trial: Mass Toxic Disasters in the Courts (1986)

82. See CALABRESI, supra note 3.

83. See, e.g., RICHARD A. POSNER, ECONOMIC ANALYSIS OF LAW (1972).

84. See, e.g., STEVen Shavel, Economic ANALysis of Accident Law (1987).

85. See, e.g., Jules L. Coleman, Risks and Wrongs (1992).

86. See, e.g., ERnest J. Weinrib, The Idea of Private Law (1995).

87. See, e.g., George Fletcher, Faimess and Utility in Tort Theory, 85 HARV. L. REV. 537 (1972).

88. See Howard Latin, "Good" Warmings, Bad Products, and Cognitive Limitations, 41 UCLA L. REv. 1193 (1994).

89. See Lawrence M. Friedman, Civil Wrongs: Personal Injury Law in the Late Nineteenth Century, 1987 AM. B. Found. J. 351, 359 [hereinafter Friedman, Civil Wrongs].

90. See Lawrence M. Friedman and Thomas D. Russell, More Civil Wrongs: Personal Injury Litigation, 1901-1910, 34 AM. J. LEGAL Hist. 295, 296 (1990).

91. See Friedman, Civil Wrongs, supra note 89, at 360. 
century, about two-thirds of the cases were brought against railroads and street railways, and although injured passengers were the most common plamtiffs, other claimants included injured workers and those involved in grade crossing accidents..$^{92}$ Medical malpractice cases were filed less than once every two years on average. ${ }^{93}$ As compared with today, a far higher proportion of the filed claims, just over $30 \%$, went to trial. Although plaintiffs won $75 \%$ of the cases that finally went to jury verdicts, defendants obtained many nonsuits and had many cases overturned on appeal, so that, in the end, plaintiffs in only $10 \%$ of the claims initially filed won damages in court. ${ }^{94}$ Of those who won and held on to their victory after appeal, no plaintiff obtained more than $\$ 14,000$, and the average award was around $\$ 3,500.95$

Today personal injury law cases are predominantly auto injury cases; data for 1996 from the nation's seventy-five largest counties shows that auto cases made up nearly half of all trials of torts cases. ${ }^{96}$ Other important categories of personal injury cases today include injuries incurred on the property of another ("slip and fall" cases as well as many other types of harms), accounting for just over $20 \%$ of large county state court torts trials in $1996,{ }^{97}$ injuries incurred in the course of medical treatment, product injuries, non-auto transportation injuries, and injuries caused by the escape of powerful forces that ought to have been under human control (explosions, fires, electricity, and the like). Many of these categories of cases were unimportant or completely absent 100 years ago for a combination of the reasons explored earlier. Perhaps most pointedly, suits in significant numbers against motorists, doctors, and product manufacturers are all a result of twentieth-century changes.

Another great difference in personal injury law today as opposed to the past is the problem of the mass injury, and the field of "mass tort" law that has come of age to try to deal with it. The difference is not merely that negligent airline compamies can and sometimes do easily kill more people all at once than just about any careless defendant could have killed at once in 1900. A few hundred airline deaths is actually small potatoes when compared with the number of injuries that some other modern products have caused. Nowadays, if certain dangerous products proliferate and cause havoc before their dangers are appreciated, enormous numbers of consumers and others can be put at risk. This has happened with asbestos,

\footnotetext{
92. See id. at 361 .

93. See id.

94. See id. at 364-65.

95. See id. at 365; see also Randolph E. Bergstrom, Courting Danger 11-30 (1992) (describing tort litigation in New York in the period 1870-1910).

96. See Brian J. Ostrom \& Neal B. Kauder, Examining the Work of State Courts, 1998: A National Perspective from the Court Statistics Project 96 (1999).

97. See id.
} 
certain birth control devices, some pharmaceutical drugs and medical appliances, and other products. And sometimes products proliferate not via purchases by victims, but through "leaks" or "escapes" into the water, air and so on. Moreover, as indicated earlier, many dangerously toxic products today do not cause acute trauma, but instead induce debilitating or deadly diseases. Cigarettes, a product that was of little importance in America in 1900, are perhaps the most important example.

Yet, as is evident from the data presented earlier, personal injury law still only deals with a small share of accidental injuries, and by no means all accidental fatalities. RAND's 1989 study found that only about $10 \%$ of all accident victims even filed claims for compensation, including $44 \%$ of auto accident victims, $7 \%$ of work accident victims, and 3\% of other accident victims. ${ }^{98}$ About half of the claimants hired a lawyer and most of those had obtained some recovery; of those who pursued their claim without a lawyer, only around half obtained any compensation. ${ }^{99}$

\section{IX}

\section{An Appraisal of How Well Tort Law Serves Our Society at the START OF THE NEW CENTURY}

\section{A. Failure on the Compensation Goal}

Decades ago Fleming James and others imagined that, were enterprise liability to become the central principle of tort law, then tort might possibly become a reasonably comprehensive mechanism for compensating accident victims. ${ }^{100}$ Yet, things have not turned out that way. First, as already noted, strict liability has so far failed as a doctrinal matter. Second, as also shown above, a substantial share of accidental injuries are not touched by personal injury law today. And they are likely to remain beyond the reach of any readily imaginable scheme of enterprise liability; to give but one example, who thinks that basketball makers (or basket makers, or basketball court makers) should really be liable for all basketball injuries? Hence if personal injury law is to be judged as a mechanism for accident compensation, it must be deemed a failure.

Its defenders instead need to focus the risk-spreading goal on the narrower question of how well our system serves to compensate those who are entitled to compensation under tort law's own rules. ${ }^{101}$ Here, too, alas, the system fares quite poorly.

98. See HeNSLER, supra note 57 , at 121.

99. See id at $124,137$.

100. See George L. Priest, The Invention of Enterprise Liability: A Critical History of the Intellectual Foundations of Modern Tort Law, 14 J. LegAL STud. 461, 470-83 (1985).

101. See generally Peter A. Bell and JefFery O'Connell, Accidental Justice: the Dilemmas OF TORT LAW 46-67 (1997). 
Most importantly, the vast majority of seriously injured auto accident victims are under-compensated because our society, as a practical matter, permits people to drive with little or no auto insurance..$^{102}$ We tolerate this situation because of the high cost of auto insurance and the burden it imposes on the poor; and yet the irony is that the cost of insurance is so high precisely because our tort law is so generous. The upshot is that our scheme dramatically favors auto accident victims with small injuries over those with large injuries. Indeed, in my view, we have things entirely upside down. We undercompensate those most in need, and yet we overcompensate those with sinall injuries by awarding thein excessive sums for transitory pain and suffering that is ordinarily long gone before the money is paid out. ${ }^{103}$

Personal injury law fails to compensate large numbers of deserving victims of many other types of wrongdoing as well. Medical malpractice is a good example. Based upon a well known Harvard study, I estimated that of every 1000 medical malpractice victims, somewhat fewer than 50 obtam compensation from personal injury law. At the same time, nearly as many claimants who are not malpractice victims are also compensated either through settlements or erroneous jury decisions. ${ }^{104}$

\section{B. Qualms about Whether Justice Is Being Served}

I am skeptical about whether a large share of those who actually bring lawsuits obtain a satisfying sense of "justice" from the system. First, hardly any claimants obtain a jury verdict in their favor, because nearly all claims are either settled or dropped. Hence, it is a rare victim who is able to hold his or her injurer accountable in court. Research conducted by the RAND Corporation's Institute for Civil Justice suggests that the claims experience is not very satisfying to victims. ${ }^{105}$ Often victims' lawyers pay little attention to them, their cases drag on seemingly forever, and suddenly they are presented with a dollar figure to accept or reject.

Those who are actively involved in litigation often have mixed experiences. There is probably a rush of excitement when the lawyer is hired and the lawsuit is filed. Enduring a deposition or cross examination in court is often harrowing. At trial, the case too often plays out to the victim in mysteriously stylized ways, and the tactics and witnesses for the defense side are frequently infuriating. To be sure, a seven figure or inore jury award is probably exhilarating; yet even that is rarely the end of it, as the

102. See Jeffrey O'Connell, A Draft Bill to Allow Choice Between No-Fault and Fault-Based Auto Insurance, 27 HARv. J. ON LEG1S. 143, 152 n.32 (1990).

103. See generally Sugarman, "Pay AT the PumP" Auto Insurance, supra note 37.

104. See Stephen D. Sugarman, Doctor No, 58 U. CHl. L. REv. 1499 (1991).

105. See HENSLER, supra note 57, at $139-40$ (noting that more than $66 \%$ of those who filed a lawsuit considered the process unfair); E. Alan Lind et al., In the Eye of the Beholder: Tort Litigants' Evaluations of their Experiences in the Civil Justice System, 24 L. \& Soc'Y. REv. 953 (1990). 
victim often has to endure years of post-verdict motions, appeals, and further settlement negotiations.

My judgment overall is that for some victims the system works fine, but for most it does not. The experience of victims is often quite different from that enjoyed by the personal injury lawyer. For many attorneys doing this work, the fight, the tension, the risk taking, and the like can be very satisfying. Moreover, many honestly believe that they represent a thin line of consumer protection against a rapacious business and insurance complex. Others, however, are cynical about their work, even if it provides them with a generous living standard.

\section{Ineffective as Punishment}

Personal injury law is sometimes defended as a means by which just punishment is visited on wrongdoers. I have always found this to be a mysterious claim as applied to the world of accidental injuries. Individual defendants are usually sued only if they have liability insurance. Enterprise defendants are not generally individuals. They are pieces of paper, and the individuals within their ranks who were at fault in causing the harm are rarely punished either by the legal system or by the enterprise itself. Personal injury law might punish (at least financially) if we, for example, required individual wrongdoers to pay at least some of the award or settlement arising out of their misconduct, but we do not.

Punitive damages are, by definition, a mechanism of punishment. They are infrequently available in personal injury cases, ${ }^{106}$ as they are not supposed to be imposed where the harm was only accidentally caused, albeit carelessly. Rather, punitive damages are meant to be reserved for much more serious wrongdoing. Even so, punitive damages are problematic as a punishment device. In most claims against individuals, their possible award may enable the plaintiff's lawyer to obtain a larger settlement, but an actual jury award of punitive damages will result only rarely, if for no other reason than most individual defendants would not be able to satisfy the judgment. And obtaining a larger settlement from an insurer hardly punishes the wrongdoer. Therefore, punitive damages are now primarily a device for punishing enterprises.

The concerns I have here are twofold. On the one hand, I doubt whether our system accurately punishes the worst corporate actors. I fear that a large number of enterprises are inappropriately subjected to punitive damages while others escape who should not, and that the sums actually awarded are highly inconsistent from case to case. On the other hand, I remain perplexed about who we think we are really punishing. Enterprises subjected to punitive damages are often publicly owned corporations. Is it

106. See 1 A.L.I., supra note 70, at 231-65. 
the shareholders we are trying to punish? But they are not the ones who acted egregiously. Is it that we are trying to devalue the stock options of executives in the firm? But that would imply that we think that all of those with stock options have engaged in horrendous behavior, which is typically not the case. It seems rather that we want to think of the corporation as a person and to punish it as an institution. But this is a flight of fancy.

\section{Deterrence-The Jury Is Still Out}

In my view, we are left, then, with behavioral channeling, the promotion of safer conduct and safer products, as the key justification for our existing system of personal injury law. Perhaps the most important contribution of the law and economics movement is the notion that personal injury law ought to be able to promote "efficient" levels of accidents-though its devotees are still fighting over whether it is a regime of negligence (which we have) or a scheme of strict liability (which others prefer) that best serves that goal. ${ }^{107}$ The proof, in any event, is not in the theory (although that helps us think about where to look for evidence). Unfortunately, empirical studies of the influence of personal injury law on enterprise behavior are extremely difficult to carry out in a convincing manner. Still, many are making the effort, and their efforts are getting more sophisticated.

When I first wrote about this issue fifteen years ago, I was quite unpersuaded that personal injury law had important positive impacts on conduct. ${ }^{108}$ I noted that for the threat of liability to matter it would have to achieve desirable improvements in safety beyond those which would have occurred anyway as a result of personal moral scruples, fear of harm to oneself, market pressures towards safe conduct, and regulatory regimes promoting safety. Moreover, I poimted out that several factors tend to undermine whatever good personal injury law might do in closing the gap between what those other forces achieved and the socially optimal level of safe conduct. These factors include the blunting impact of insurance, trumping interests that cause actors deliberately to risk danger to others despite the possibility of tort liability, and limits on the ability of enterprises to control those in their employ.

These considerations made me extremely dubious that the threat of personal injury law makes for safer drivers or better doctors, and yet, even

107. See, e.g., Steven P. Croley \& Jon D. Hanson, Rescuing the Revolution: The Revival Case for Enterprise Liability, 91 MicH. L. REv. 683 (1993); Jon D. Hanson \& Kyle D. Logue, The First-Party Insurance Externality: An Economic Justification for Enterprise Liability, 76 CORNELL L. REv. 129 (1990).

108. See Stephen D. Sugarman, Doing Away With Personal Injury Law 3-34 (1989); Stephen D. Sugarman, Doing Away with Tort Law, 73 CALIF. L. REv. 555, 559-90 (1985). 
in these areas, some authors have claimed positive results for tort law. ${ }^{109}$ Other scholars have emphasized that personal injury law's main promise lies in directing corporate behavior in desirable directions, and some empirical evidence has been marshaled in support of that prediction (although others have pointed to socially undesirable impacts the threat of tort law seems to have on corporate innovation in certain industries). ${ }^{110}$

I suppose that a fair appraisal as we start the twenty-first century is that the jury is still out on this issue. What remains clear to me is that, as a society, despite the urging of some of the law and economics crowd, we are quite unwilling to rely on tort law alone to regulate the risk of accidents. That is, we are decidedly not ready to give up our regulatory and criminal regimes directed towards safety. Hence, the real policy issue is what sort of mixture of personal injury law and other regulatory mechanisms work best for the money, recognizing that personal injury law carries very high transaction costs to operate. ${ }^{11}$

Some scholars believe that personal injury law serves additional important social functions that are somehow different from the fairness and deterrence goals. One claim is that personal injury claims help to alert administrative agencies of dangerous products and activities that the agencies would otherwise be slower to regulate. Another claim is that through personal injury law we satisfy our collective need to identify and assign blame for wrongdoing when fellow members of society are hurt by that misconduct. Yet another claim is that through jury processing of individual cases we best develop a social consensus about what are the reasonable precautions that members of our society should take to protect others from harm. Recently, Peter Bell and Jeffrey O'Connell have thoughtfully written about these and related social benefits that may be achieved by tort law today. ${ }^{112}$ I agree that what might be called "ombudsman," "educational," or "political" benefits, as well as other possible benefits of the personal injury law system, deserve further attention. But it must be remembered that the overwhelming majority of personal injury law claims that are filed, that is, routine cases that are almost always settled or abandoned, have almost nothing to do with these objectives.

109. See, e.g., Gary T. Schwartz, Reality in the Economic Analysis of Tort Law: Does Tort Law Really Deter?, 42 UCLA L. Rev. 377 (1994); BeLl \& O'CoNnell, supra note 101, at 68-100.

110. See Don Dewees et al., Exploring the Domain of Accident law: Taking the Facts Seriously (1996); The Liability Maze: The IMPaCt of Liability LaW on Safety and InNovation (Peter W. Huber \& Robert A. Litan, eds., 1991).

111. See James S. Kakalik \& Nicholas M. Pace, Costs and Compensation Pain in Tort LITIGATION (1986).

112. See BELL \& O'CONNELL, supra note 101, at 138-69. 
$\mathrm{X}$

LOOKING AHEAD

In thinking about the place personal injury law will have in the twenty-first century, I find myself dwelling on the billions of dollars in legal fees that trial lawyers are beginning to obtain from their role in tobacco litigation and the ability those trial lawyers may have to deploy even a small share of that inoney in politically effective ways. That is not to say that the plaintiffs' bar always wins. After all, one important recent experience in California is to the contrary.

In the late 1970s, when liberal, pro-plaintiff, Democratic appointees controlled the California Supreme Court, the judges decided that defendants' insurers committed a tort and were subject to both compensatory and punitive damages if they failed to act in good faith in their negotiations with the plaintiff and the plaintiff's lawyer. ${ }^{113}$ Ten years later, when Republican appointees dominated the California Supreme Court, this tort was abolished, the Court noting that only California had recognized such a cause of action. ${ }^{114}$ In 1999, as soon as the Democrats finally regained control of the state's governorship, senate, and assembly, a statute was passed to reinstate this bad faith cause of action. But then in early 2000 the voters rejected the law in a referendum election. ${ }^{115}$ Put simply, that election was won by the insurance industry, whose TV commercials and mass mailings overcame the campaign waged by the trial lawyers on the other side.

But just as this experience suggests that the insurance industry can sometimes defeat legal changes sought by the plaintiffs' bar, so too the past fifteen years have shown that the trial lawyers can frequently defeat changes sought by insurers and other defense interests. Much legislative tort law reform during this period has been of the "roll back victims" rights" sort, ${ }^{116}$ and although most states have passed some of these "reforms," few have adopted strong comprehensive reforms. Where that has happened, state courts have often stepped in at the behest of the trial lawyers and struck the reforms down. ${ }^{117}$ At the ballot box, the insurance industry has been quite unsuccessful in selling auto no-fault to the public. ${ }^{118}$

113. See Royal Globe Ins. Co. v. Superior Court, 592 P.2d 329, 333-35 (Cal. 1979).

114. See Moradi-Shalal v. Fireman's Fund Ins. Cos., 758 P.2d 58, 63-64, 68 (Cal. 1988).

115. See Vote 2000-California Primary Election (visited June 27, 2000) <http://www.vote2000.ss.ca.gov/ returns/prop/00.htm>.

116. See Sugarman, Doing AWay WiTh Personal Injury Law, supra note 108, at 75-99.

117. See, e.g., Knowles v. United States, 544 N.W.2d 183 (S.D. 1996) (rejecting malpractice damages as unconstitutional).

118. For example, in 1988 and in 1996, California voters defeated insurance industry-supported auto no-fault plans, propositions 104 and 200. See California Ballot Proposition Database, Hastings College of the Law Library (visited July 10, 2000) <http://www.holmes.hastings.edu>. 
Given the ability of the competing special interest groups to block changes sought by the other side, one should not expect a great deal of change in personal injury law itself. To be sure, during the $1990 \mathrm{~s}$, courts in some states have become somewhat more pro-defendant in terms of personal injury law doctrine, and this trend may continue. ${ }^{119}$ So, too, juries in some places (but decidedly not in others) are becoming less extravagant in what they award. But these are changes of modest scope. ${ }^{120}$

The prospects for more dramatic change will probably require some outside factor to enter into play. Another crisis in auto insurance rates, for example, could trigger a new round of interest in auto no-fault plans. Auto no-fault advocates, led by Jeffrey O'Connell (personal injury law's most inventive reformer), this time have "auto choice" plans at the ready. ${ }^{121}$ The idea behind these plans is that individual drivers should be able to elect to be in either the fault or the no-fault regime as they wish-an ingenious notion that could catch on in the right circumstances, especially if motorists could be made to understand how much of their auto insurance premium they could save by electing the no-fault option. ${ }^{122}$

Similarly, growing tensions in managed care and ongoing pressures for more comprehensive health insurance schemes could trigger reform in the medical malpractice field. Paul Weiler's nifty proposal to replace medical malpractice law with a no-fault scheme covering all serious medical accidents could finally get a full airing. ${ }^{123}$

Erosion of the role of personal injury law from within remains a possibility. Several states have already reversed the collateral sources rule, thereby awarding tort damages only for medical expenses and wage loss not covered by social insurance and health care plans. ${ }^{124}$ More might be coaxed to do so if Americans obtain better compensation arrangements to cover those out-of-pocket expenses that tort is meant to compensate. The simple point here is that if tort were only to compensate for losses not otherwise covered, and if those collateral sources grow, then tort would recede.

119. See Gary T. Schwartz, The Beginning and the Possible End of the Rise of Modern American Tort Law, 26 GA. L REv. 601 (1992); Stephen D. Sugarman, Judges as Tort Law Un-Makers: Recent California Experience with "New" Torts, 49 DEPAUL L. REV. 455 (1999).

120. See James A. Henderson, Jr., \& Theodore Eisenberg, The Quiet Revolution in Products Liability, 37 UCLA L. REv. 479 (1990).

121. See Jeffrey O'Connell et al., The Costs of Consumer Choice for Auto Insruance in States Without No-Fault Insurance, 54 MD. L. REv. 281 (1995); Stephen D. Sugarman, Choosing Among Systems of Auto Insurance for Personal Injury, 26 SAN Diego L. REv. 977 (1989).

122. See Stephen Carroll, Effects of an Auto-Choice Automobile Instrance Plan on Costs and Premiums (visited July 13, 2000) <http://www.rand.org/publications/CT/CT141/>.

123. See Paul C. Weiler, Medical. Malpractice on Trial (1991).

124. See Marc A. Franklin \& Robert L. Rabin, Tort Law and Alternatives 692 (6th ed. 1996). 
Again, the adoption of comprehensive health insurance could play a role here. Moreover, although improving Social Security's reach was thought impossible during the past decade when the future bankruptcy of Social Security was most on people's mind, the picture is now beginning to change as the existing federal debt is possibly on its way to disappearing and the health of Social Security's future is being secured. At a minimum, before too long I predict that calls for turning workers' compensation into an around-the-clock scheme will resurface. ${ }^{125}$ Rather than broadening workers' compensation itself, however, a different solution is imaginable. It would imvolve parceling out workers' compensation's functions to other regimes: for example, the health care portion could go to comprehensive health insurance and the wage replacement function could go to a combination of Social Security plus a new employment-based scheme for short tern disability. ${ }^{126}$

Another potential source for the erosion of the role of personal imjury law is the voluntary relinquishment of the right to sue. Already in the health care field we see a growing shift to people's willingness to commit in advance to arbitration of personal injury claims rather than litigation. This trend could expand. Even more dramatically, several writers have imagined other ways in which potential victims could parlay their potential personal injury law rights in advance into more attractive financial benefits. ${ }^{127}$ This could possibly turn personal injury law into a simpler, interinsurance company administrative scheme.

Potentially important, too, are changes in our regulatory regimes. As I suggested earlier, many of those who laud personal mjury law as an effective promoter of accident prevention also criticize most other public forms of regulation. Yet, as I stated above, I do not believe that our major regulatory systems are very much at risk of being dismantled. At the same time it remains unclear whether our society will ever have sufficient confidence in those other regimes to let go of personal injury law as a parallel deterrence mechanisin. If the public really believes that the personal injury lawyer serves a socially valuable function both in exposing and preventing enterprise misconduct, then we should look for ways to de-couple this function from the function of providing accident victim coinpensation. Lawyers and victims who first identify and prove unreasonably dangerous corporate behavior would need to be amply rewarded for that work without using the apparatus of personal injury law as we know it.

125. See Stephen D. Sugarman, Serious Tort Law Reform, 24 SAN Diego L. Rev. 795 (1987).

126. See Stephen D. Sugarman, Short Term Paid Leave: A New Approach to Social Insurance and Employee Benefits, 75 CALIF. L. REv. 465 (1987).

127. See Robert Cooter \& Stephen D. Sugarman, A Regulated Market in Unmatured Tort Claims: Tort Reform by Contract, in New DiRECTIONS IN Liability LaW 174 (Walter Olson ed., 1988). 
One fairly moderate package that would move our society in that direction would include the reversal of the collateral sources rule, the imposition of a high threshold of harm before victims may recover pain and suffering damages, plus the creation of easier access to both moderate punitive damages and the payment of plaintiffs' legal fees from serious wrongdoers. But those punitive damages and legal fees would only be available to those who actually serve our society by ferreting out seriously at-fault behavior.

In the end, the role of personal injury law at the end of the twenty-first century is probably as unpredictable as its current role was at the end of the nineteenth. Not only might personal injury law doctrine and the background institutions to tort law change significantly, but also technological advances may well change the pattern of accidental bodily injury that will exist 100 years from now in ways we cannot anticipate. 